\title{
Implications of mitotic and meiotic irregularities in common beans (Phaseolus vulgaris L.)
}

D.C. Lima ${ }^{1}$, G.T. Braz ${ }^{1}$, G.B. dos Reis ${ }^{1}$, V.H. Techio ${ }^{1}$, L.C. Davide ${ }^{1}$ and A. de F.B. Abreu ${ }^{2}$

${ }^{1}$ Departmento de Biologia/Genética e Melhoramento de Plantas, Universidade Federal de Lavras, Lavras, MG, Brasil

${ }^{2}$ Embrapa Arroz e Feijão, Santo Antônio de Goiás, GO, Brasil

Corresponding author: V.H. Techio

E-mail:vhtechio@dbi.ufla.br

Genet. Mol. Res. 15 (2): gmr.15027749

Received September 29, 2015

Accepted November 11, 2015

Published May 23, 2016

DOI http://dx.doi.org/10.4238/gmr.15027749

\begin{abstract}
The common bean has great social and economic importance in Brazil and is the subject of a high number of publications, especially in the fields of genetics and breeding. Breeding programs aim to increase grain yield; however, mitosis and meiosis represent under explored research areas that have a direct impact on grain yield. Therefore, the study of cell division could be another tool available to bean geneticists and breeders. The aim of this study was to investigate irregularities occurring during the cell cycle and meiosis in common bean. The common bean cultivar used was BRSMG Talismã, which owing to its high yield and grain quality is recommended for cultivation in Brazil. We classified the interphase nuclei, estimated the mitotic and meiotic index, grain pollen viability, and percentage of abnormalities in both processes. The mitotic index was $4.1 \%$, the interphase nucleus was non-reticulated, and 19\% of dividing somatic cells showed abnormal behavior. Meiosis also presented irregularities resulting in a meiotic index of $44.6 \%$. Viability of pollen grains was $94.3 \%$. These results indicate that the common bean cultivar
\end{abstract}


BRSMG Talismã possesses repair mechanisms that compensate for changes by producing a large number of pollen grains. Another important strategy adopted by bean plants to ensure stability is the elimination of abnormal cells by apoptosis. As the common bean cultivar BRSMG Talismã is recommended for cultivation because of its good agronomic performance, it can be concluded that mitotic and meiotic irregularities have no negative influence on its grain quality and yield.

Key words: Incompatibility; Meiosis; Mitosis; Phaseolus vulgaris L.; Pollen viability

\section{INTRODUCTION}

The common bean has great social and economic importance in Brazil. Its social importance is attributed to the fact this crop is the main source of vegetable protein and nutrients for the population, especially for people on low incomes. Economically, the common bean is grown over more than three million hectares by a huge contingent of farmers, including typical farmers and large rural entrepreneurs (Wander, 2014).

Because of its importance and its short cycle, the common bean is the subject of a high number of publications by Brazilian researchers, especially with regards to its genetics and breeding. One of the main goals of breeding is to increase grain yield, which is a complex trait that depends on most of this species' genes. However, aspects related to mitosis and meiosis remain poorly explored, which ultimately have a direct impact on grain yield. Therefore, investigating irregularities during cell division represents another tool available to common bean geneticists and breeders.

Studies on the cytogenetics of the genus Phaseolus are lacking in the literature. The chromosome number in this genus was first reported in 1925 when Karpetschenko (1925) showed it to be $2 n=22$ for some species, including Phaseolus vulgaris L., which is one of the most important species of the genus (Mercado-Ruaro and Delgado-Salinas, 2000; Bonifácio et al., 2012). Initial work aimed to establish the basic chromosome number, which is $\mathrm{x}=11$ (Lackey, 1979; Mercado-Ruaro and Delgado-Salinas, 1998). Karyotype analysis to differentiate species within Phaseolus revealed variations within the genus, and there are reports of species with $\mathrm{x}=10$ (Mercado-Ruaro and Delgado-Salinas, 1998, 2009). Chromosomes are small (about $2 \mathrm{~mm}$ ) and have similar morphologies (Fonsêca et al., 2010). Available data show that there is a predominance of metacentric and submetacentric chromosomes, which result in very symmetrical karyotypes.

Therefore, this study aimed to investigate irregularities occurring during the cell cycle and meiosis in the common bean cultivar BRSMG Talismã in order to obtain information that can guide future research into cytogenetics with emphasis on this species of great social and economic importance.

\section{MATERIAL AND METHODS}

\section{Plant material}

This study evaluated the common bean cultivar BRSMG Talismã, which has been 
recommended since 2002 (Abreu et al., 2004), as a result of the partnership between the Universidade Federal de Lavras (UFLA), Federal University of Viçosa, Research Company of Minas Gerais State and Embrapa Arroz e Feijão (Brazilian Research Institution). The seeds were provided by the Program in Genetics and Breeding of Common Beans of UFLA. The botanical material used in the present study belongs to the active germplasm bank of the program, at the Department of Biology of UFLA, Lavras, Minas Gerais State, Brazil.

\section{Cell cycle analysis}

For this analysis, root tips were obtained from seeds of different plants germinated at $28^{\circ} \mathrm{C}$ on Petri dishes containing moistened filter paper and cotton. Roots were fixed and stored in Carnoy's solution (ethanol: glacial acetic acid, $3: 1$ ) at $-20^{\circ} \mathrm{C}$ until slide preparation. Roots were subjected to enzymatic maceration in a solution containing pectinase/cellulase $(100 / 200 \mathrm{U})$ for $30 \mathrm{~min}$ at $37^{\circ} \mathrm{C}$ in a humidity chamber or hydrolysis with $1 \mathrm{~N} \mathrm{HCl}$ solution in a water bath $\left(60^{\circ} \mathrm{C}\right)$ for $10 \mathrm{~min}$. Slides were mounted by the squash technique and stained with $5 \%$ Giemsa for $5 \mathrm{~min}$. The cell cycle was evaluated in 38,865 cells on 20 slides by estimation of the mitotic index $(\mathrm{MI}=$ number of normal cells/total cells). Interphase nuclei were classified based on the description by Guerra (1985). We also determined the percentage of abnormalities in dividing cells.

\section{Meiotic analysis}

Young floral buds smaller than $2 \mathrm{~mm}$ were collected around 8:00 a.m. from random plants kept in the greenhouse and in the field. The flower buds were fixed in Carnoy's solution and stored at $-20^{\circ} \mathrm{C}$ until slides were prepared. Thereafter, three washes of 5 min each were performed with distilled water and anthers were cut under a stereomicroscope. Next, anthers were subjected to enzymatic treatment $(0.1 \mathrm{~g}$ cytohelicase, $0.375 \mathrm{~g}$ sucrose, $0.25 \mathrm{~g}$ polyvinylpyrrolidone) in a water bath at $33^{\circ} \mathrm{C}$ for $1 \mathrm{~h} 15 \mathrm{~min}$. Three washes of $5 \mathrm{~min}$ each were then performed using ice-cold distilled water. After this, meiocytes were carefully extracted from the anthers, macerated, and stained with $2 \%$ propionic carmine. We evaluated 629 meiocytes and estimated the percentage of abnormalities. The meiotic index was calculated after the evaluation of 166 tetrads (IMe $=$ number of normal tetrads/total tetrads).

To determine pollen viability, pollen grains were extracted from anthers following the same procedure performed for the meiotic analysis, and then stained with Alexander dye (Alexander, 1980). Pollen grains were considered viable when they showed a purple coloration and unviable when they were green. A total of 1880 pollen grains were evaluated. All slides were analyzed under a light microscope (Zeiss) equipped with a micro camera (AxioCamICc1) for image scanning.

\section{RESULTS}

The common bean cultivar BRSMG Talismã presented a mitotic index of $4.1 \%$, with 37,282 interphase cells. No abnormalities were found in interphase. Interphase nuclei showed a consistent pattern and were classified as non-reticulated, i.e., without condensed euchromatin and with distinct chromocenters, while the rest of the nucleus was almost non-stainable (Figure 
1) (Guerra, 1985). Abnormal somatic cells represented 19\% of all dividing cells (Table 1). Among the abnormalities observed during the cell cycle (Figure 2), the atypical structure of the metaphase plate stood out, wherein the cells showed two parallel sets of chromosomes on the plate, which may or may not be of similar size (Figure 2A and 2B, respectively). Furthermore, we verified colchicine metaphases (Figure 2C) and non-oriented chromosomes on the metaphase plate (Figure 2D). In anaphase, we identified late chromosomes (Figure 2E), asynchrony (Figure 2F), and the formation of three sets of chromatids, two parallel sets on a plate, as well as a larger set (Figure 2G). Condensed nuclei, which are cytological markers of cell death, were found at a very low frequency $(0.27 \%$ of total cells) (Figure $2 \mathrm{H})$.

Table 1. Percentage of mitotic abnormalities in the common bean cultivar BRSMG Talismã.

\begin{tabular}{l|c|c|c|c|c}
\hline & Prophase & Metaphase & Anaphase & Telophase & Total \\
\hline Normal & $9.2(146)^{*}$ & $45.5(719)$ & $24.2(383)$ & $2.0(32)$ & $81.0(1280)$ \\
\hline Abnormal & $0.3(4)$ & $13.6(216)$ & $4.4(70)$ & $0.7(11)$ & $19.0(301)$ \\
\hline
\end{tabular}

*Absolute number of cells in brackets.

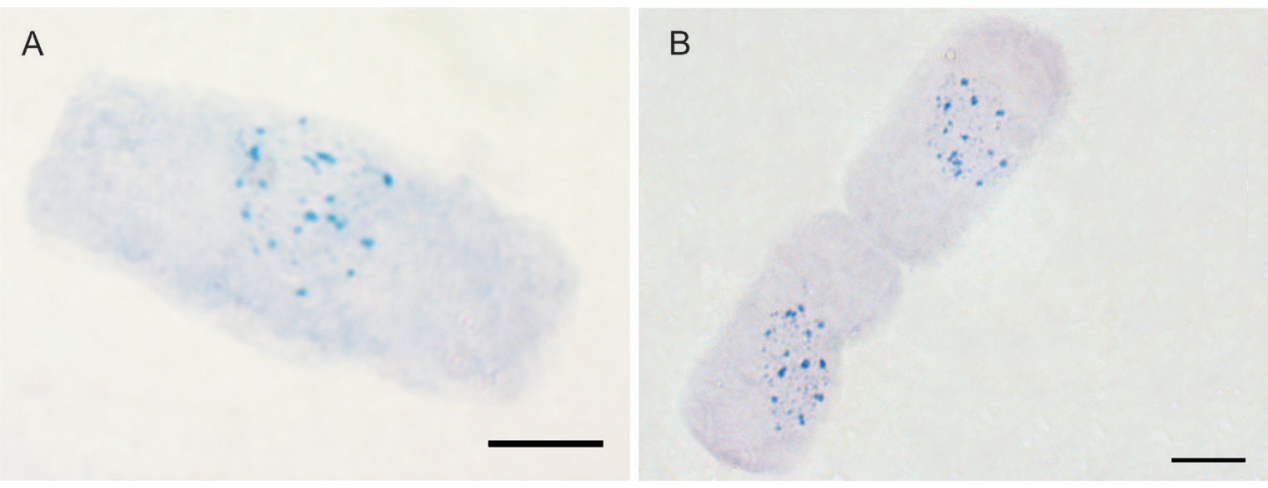

Figure 1. Interphase nuclei of the common bean cultivar BRSMG Talismã. Bar $=10 \mathrm{~mm}$.

Due to the observation of mitotic abnormalities, the meiotic behavior of the cultivar was observed in order to ascertain whether the observed changes could be transmitted to descendants or were restricted to somatic tissue. Meiosis also presented irregularities, reflected in the estimated meiotic index of $44.6 \%$. Chromosome segregation was irregular in approximately $47 \%$ of the evaluated meiocytes (Table 2). The abnormalities noted in Table 2 included the formation of two sets of parallel and unequal chromosomes at metaphase I (Figure 3A), asynchronous prophase II (Figure 3B), asynchronous metaphase II (Figure 3C), and the formation of bridges in anaphase II (Figure 3D). In telophase I and II, the formation of micronuclei in different numbers and sizes were noted (Figures 3E-H). This also occurred in the evaluated tetrads (Figure 4C). Triads were also observed, without micronuclei (Figure $4 \mathrm{~A}$ and $\mathrm{B}$ ). Regarding the frequency of abnormalities, a low viability of pollen grains was expected; however, the estimated value to the pollen viability was $94.3 \%$. Pollen grains were considered viable when stained purple (Figure 4D) and unviable, when stained green (Figure 4E). Unviable pollen grains were observed, which were larger in size (Figure 4F). 




Figure 2. Abnormalities in the mitotic cycle of the common bean cultivar BRSMG Talismã. A. Two parallel sets of chromosomes on the metaphase plate. B. Two parallel and dissimilar sets of chromosomes on the metaphase plate. C. C-metaphase. D. Non-oriented chromosomes. E. Late-anaphase chromosomes. F. Asynchronous anaphase. G. Anaphase with one of the plates having two sets of chromatids. H. Condensed nuclei. Bar $=10 \mathrm{~mm}$.



Figure 3. Abnormality in the different stages of meiosis in the common bean cultivar BRSMG Talismã. A. Two sets of parallel and uneven chromosomes on the metaphase plate of meiosis I. B. Asynchronous prophase II. C. Asynchronous metaphase II. D. Anaphase II with bridge. E. Telophase I with one micronucleus. F. Telophase I with three micronuclei. G. H. Telophase II with micronuclei. Bar $=10 \mathrm{~mm}$. 

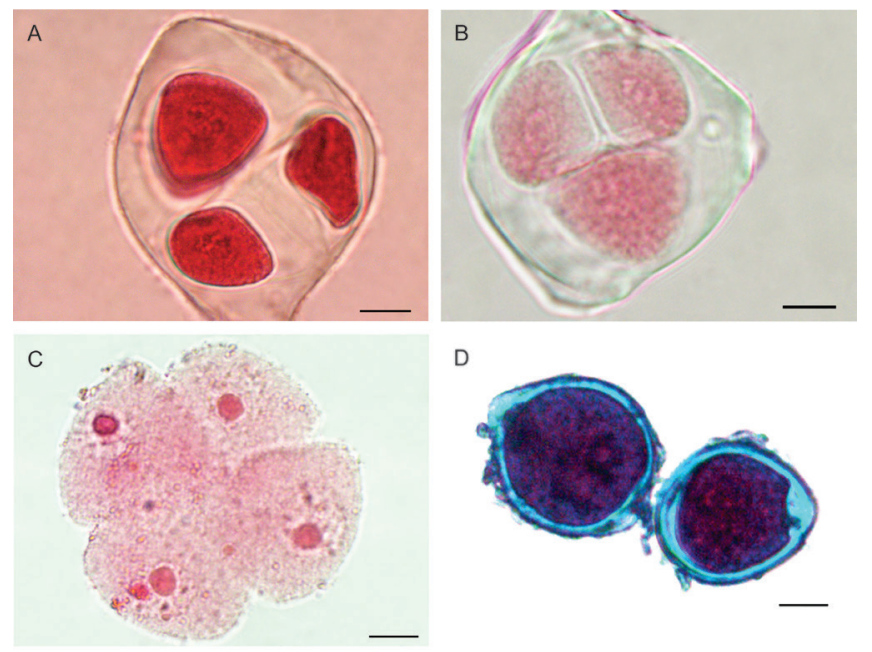

$\mathrm{D}$

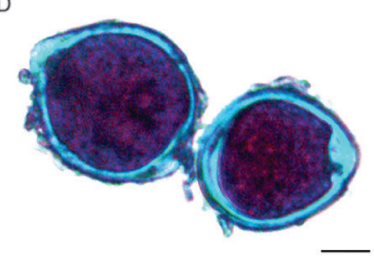

$\mathrm{E}$

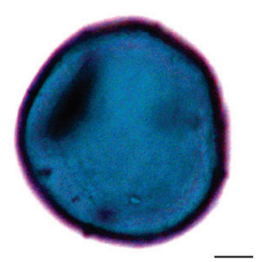

$\mathrm{F}$



Figure 4. Abnormalities at the end of meiosis and pollen grains of the common bean cultivar BRSMG Talismã. A. B. Triads. C. Tetrad with micronuclei. D. Viable pollen grains. E. Unviable pollen grains. F. Viable pollen grain (left) and unviable (right). Bar $=10 \mathrm{~mm}$.

Table 2. Percentage of abnormalities in meiosis in the common bean cultivar BRSMG Talismã.

\begin{tabular}{l|c|c}
\hline & Normal & Abnormal \\
\hline Prophase I & $1.0(6)^{*}$ & $0.8(5)$ \\
\hline Metaphase I & $2.5(16)$ & $1.6(10)$ \\
\hline Anaphase I & $1.0(6)$ & $0.6(4)$ \\
\hline Telophase I & $0.8(5)$ & \\
\hline Prophase II & $10.5(66)$ & $7.6(48)$ \\
\hline Metaphase II & $8.3(52)$ & $3.3(21)$ \\
\hline Anaphase II & $7.9(50)$ & $19.4(122)$ \\
\hline Telophase II & $8.3(52)$ & $11.6(73)$ \\
\hline Tetrad & $11.8(74)$ & $1.7(11)$ \\
\hline Abnormal with 1 micronucleus & & $1.3(8)$ \\
\hline Abnormal with 2 micronuclei & & \\
\hline Triad & & \\
\hline
\end{tabular}

*Absolute number of cells in brackets.

\section{DISCUSSION}

The cultivar BRSMG Talismã was used in this study because it is an improved cultivar that has been recommended for use in Brazil since 2002 and has several phenotypes of interest to farmers (Abreu et al., 2004). Despite the phenotypic and molecular characterization of this 
cultivar (Abreu et al., 2004; Souza et al., 2005), no study has been conducted in relation to its cytogenetic features (i.e., meiosis and cell cycle).

Normally during mitosis, the formation of two daughter cells is expected, which are identical to the mother cell. In addition, it is expected that all phases of the cycle occur perfectly, especially DNA replication, orientation of the chromosomes on the metaphase plate, and segregation of chromatids. Any change can affect the duration of this process and the formation of daughter cells. In the cells of the cultivar BRSMG Talismã, the highest frequency of abnormalities observed in the cell cycle occurred during metaphase. In the later stages of the cell cycle, there was a reduction of this amount and it could be inferred that some of the non-oriented chromosomes observed during this phase, segregated properly. The same is true when considering the late anaphase chromosomes.

This observation reflects part of the cell cycle control system, which ensures the stability and regularity of cell division. Studies of cell cycle control and associated repair pathways have showed that cells have complex signaling pathways, known as checkpoints, which recognize and stop the cell cycle in the presence of DNA or chromosomal damage (Kaufmann and Paules, 1996; Melo and Toczyski, 2002). Checkpoints monitor the structure of chromosomes, co-ordinate DNA repair, and ensure the correct order of events throughout cell cycle progression (Blain et al., 2003). Generally, when the mitotic checkpoint fails, the extent of separation errors is severe and is incompatible with cell survival (Kops et al., 2005). In the case of the cultivar studied, the presence of cells with condensed nuclei, which is characteristic of apoptosis, indicated that this is the primary way in which the plant eliminates uneven cells.

During meiosis, chromosomes that are not oriented in metaphase and are late to enter anaphase may be the cause of micronuclei found in telophases I and II and of tetrads. These abnormalities contributed to the formation of abnormal microspores, with a very low frequency of weak or non-stained material. The formation of different sized pollen grains can occur due to disturbances in the formation of spindle fibers with the separation of the metaphase plate, asynchrony in segregation, and elimination of chromosomes culminating in an unbalanced number of chromosomes and non-viable gametes. Triads are related to the formation of larger pollen grains, possibly with the formation of $2 n$ gametes.

In some species, the mechanisms that lead to the formation of $2 n$ gametes have been well-studied (Ramanna and Jacobsen, 2003). In potato (Solanum tuberosum), for example, the control of these mechanisms is known, and the recessive allele $p s$ is responsible for the formation of parallel spindles in metaphase II. The allele $f_{s}$ is responsible for the merging of the two chromosomes sets, also in metaphase II. These two alleles promote the first division restitution (Hanneman, 1999). The products of the $p c 1$ and $p c 2$ genes are responsible for the omission of the second meiotic division, causing premature cytokinesis with the formation of dyads or triads (Mok and Peloquin, 1975). Because of differences in the ploidy level between wild and cultivated potato species, the production of unreduced gametes by the diploid wild species permits crossing with dihaploids of the cultivated potato, which is tetraploid. These crossings can be used for the introgression of genes of interest from wild species to the cultivated species (Carputo et al., 1997; Ramanna and Jacobsen, 2003).

These mechanisms differ according to species. In potato, the control of these mechanisms is understood, unlike in the common bean, in which it is not. Obtaining polyploid beans could be simplified by understanding and manipulating the mechanisms that drive the formation of unreduced gametes. 
High pollen viability was not expected in the studied cultivar, since the frequency of abnormalities was high. This indicates that the plant has repair mechanisms and compensates for changing with the production of a large number of pollen grains. Another important strategy adopted by this cultivar is the prevention of defective pollen grain formation, which was evidenced by fragmented nuclei at telophase and is a strong indicative of apoptosis. This was observed in mitotic cells.

Moreover, the high proportion of viable pollen grains may have been due to estimates of viability being made using Alexander dye, whereby not all stained pollen grains would necessarily be fertile. Although the methodology is efficient and provides clear distinction between viable and unviable pollen, this staining method does not provide information about the quality of genetic material and only indicates the fertility of the male gametes.

The meiotic index provides information about the stability of a genotype's meiosis. Usually, pollen grains fertility is correlated with meiotic abnormalities, as it depends on the efficiency of the meiotic process. Meiosis is essential for the formation of gametes, which are the agents that transmit alleles to offspring. A normal tetrad is expected to result in four viable pollen grains, each with a different genetic constitution. Thus, greater stability implies greater variability after crossings. The cultivar BRSMG Talismã is therefore not indicated for use in hybridizations in a breeding program, as it presented unstable meiosis. Nevertheless, field observations and yield results show that this does not occur. Besides being a cultivar that stands out for grain yield, as already mentioned, it was also considered a good parent in crosses made by Gonçalves-Vidigal et al. (2008).

One explanation for these abnormalities may be the different origins of the parents. This cultivar is derived from a recurrent selection program, which includes Andean and Mesoamerican parents (Abreu et al., 2004; Ramalho et al., 2005). This classification of common beans into Andean and Mesoamerican was held due to the geographic isolation that occurred during their domestication (Hannah et al., 2000; Vieira et al., 2005) and has several implications for the improvement of common bean. Beans of these gene pools differ in various characteristics, especially in the type of phaseolin, grain size, and their resistance to pathogens (Gepts and Debouck, 1991).

This fact attracted the interest of breeders in terms of the use of hybridizations between gene pools, with the theory that it would generate greater genetic variability with the possibility of greater success in selection (Singh and Urrea, 1995; Abreu et al., 1999). However, the generation of higher genetic diversity by crossing Andean and Mesoamerican cultivars in several situations is not possible due to the occurrence of genetic incompatibility in the $\mathrm{F}_{1}$ plants (Vieira et al., 2005). This incompatibility is manifested by dwarfism or weakness in the $F_{1}$ hybrid, whose plants die or have poor growth, and exhibit a number of changes including sterility, reduced root growth, chlorotic leaves, absence of roots, and the formation of adventitious roots on the hypocotyl region (Vilarinho et al., 2004; Vieira et al., 2005; Arantes et al., 2008).

According to Singh and Gutierrez (1984), incompatibility is governed by two genes, an example of double-recessive epistasis. Andean plants have the genotype $\mathrm{dl}_{1} \mathrm{dl}_{1} \mathrm{DL}_{2} \mathrm{DL}_{2}$ and the Mesoamerican plants have the genotype $\mathrm{DL}_{1} \mathrm{DL}_{1} \mathrm{dl}_{2} \mathrm{dl}_{2}$. In the $\mathrm{F} 1$ generation, the genotype would be $\mathrm{DL}_{1} \mathrm{dl}_{1} \mathrm{DL}_{2} \mathrm{dl}_{2}$, and the presence of dominant alleles of the two genes would lead to incompatibility. However, Arantes et al. (2008) observed that the 'incompatibility' trait has a very variable expression, and there is variation in the plant development stage in which the symptoms manifest. 
No studies could be found in the literature on the cell cycle or on meiosis involving a comparison between beans of these gene pools. Therefore, it is important to conduct further work in Andean and Mesoamerican beans and the $\mathrm{F}_{1}$ generation arising from the cross between these two gene pools, in order to verify this hypothesis.

It is important to emphasize, however, that even abnormalities that occur in the cell cycle and during meiosis in the cultivar BRSMG Talismã, do not interfere with the yield and quality of the grain, given the performance it shows under field conditions (Abreu et al., 2004).

In conclusion, abnormalities occurring during the cell cycle and in meiosis of the cultivar BRSMG Talismã do not affect the yield and quality of grain. The cultivar BRSMG Talisma has the potential to produce unreduced gametes.

\section{Conflicts of interest}

The authors declare no conflict of interest.

\section{ACKNOWLEDGMENTS}

Research supported by Coordenação de Aperfeiçoamento de Pessoal de Nível Superior (CAPES), Conselho Nacional de Desenvolvimento Científico e Tecnológico (CNPq), and Fundação de Apoio à Pesquisa do Estado de Minas Gerais (FAPEMIG).

\section{REFERENCES}

Abreu A de FB, Ramalho MAP and Ferreira DF (1999). Selection potential for seed yield from intra and inter racial populations in common bean. Euphytica 108: 121-127. http://dx.doi.org/10.1023/A:1003608310384

Abreu A de FB, Ramalho MAP, Carneiro JES, Gonçalves FMA, et al. (2004). 'BRSMG Talismã: common bean cultivar with Carioca grain type. Crop Breed. Appl. Biotechnol. 4: 372-374. http://dx.doi.org/10.12702/1984-7033.v04n03a21

Alexander MPA (1980). A versatile stain for pollen fungi, yeast and bacteria. Stain Technol. 55: 13-18. http://dx.doi. org $/ 10.3109 / 10520298009067890$

Arantes L de O, Ramalho MAP and Abreu AFB (2008). Controle genético da incompatibilidade do cruzamento entre cultivares andinas e mesoamericanas de feijoeiro comum. Cienc. Agrotec. 32: 978-980. http://dx.doi.org/10.1590/ $\underline{\text { S1413-70542008000300041 }}$

Blain SW, Scher HI, Cordon-Cardo C and Koff A (2003). p27 as a target for cancer therapeutics. Cancer Cell 3: 111-115. http://dx.doi.org/10.1016/S1535-6108(03)00026-6

Bonifácio EM, Fonsêca A, Almeida C, Dos Santos KG, et al. (2012). Comparative cytogenetic mapping between the lima bean (Phaseolus lunatus L.) and the common bean (P. vulgaris L.). Theor. Appl. Genet. 124: 1513-1520. http:// dx.doi.org/10.1007/s00122-012-1806-x

Carputo D, Barone A, Cardi T, Sebastiano A, et al. (1997). Endosperm balance number manipulation for direct in vivo germplasm introgression to potato from a sexually isolated relative (Solanum commersonii Dun.). Proc. Natl. Acad. Sci. USA 94: 12013-12017. http://dx.doi.org/10.1073/pnas.94.22.12013

Fonsêca A, Ferreira J, dos Santos TR, Mosiolek M, et al. (2010). Cytogenetic map of common bean (Phaseolus vulgaris L.). Chromosome Res. 18: 487-502. http://dx.doi.org/10.1007/s10577-010-9129-8

Gepts P and Debouck DG (1991). Origin, domestication, and evolution of the common bean, Phaseolus vulgaris. In: Common beans: research for crop improvement (Van Schoonhoven A and Voysest O, eds.). CIAT, Cali, p7-53.

Gonçalves-Vidigal MC, Silvério L, Elias AT, Vidigal Filho PS, et al. (2008). Combining ability and heterosis in common bean cultivars. Pesquisa Agropecu. Bras. 43: 1143-1150. http://dx.doi.org/10.1590/S0100-204X2008000900007

Guerra MS (1985). Estrutura e diversificação dos núcleos interfásicos em plantas. In: I Colóquio sobre Citogenética e Evolução de Plantas. Anais, Piracicaba, 137-153.

Hannah MA, Iqbal MJ and Sanders FE (2000). The DL gene system in common bean: a possible mechanism for control of root-shoot partitioning. New Phytol. 147: 487-496. http://dx.doi.org/10.1046/j.1469-8137.2000.00711.x 
Hanneman RE, Jr. (1999). The reproductive biology of the potato and its implication for breeding. Potato Res. 42: 283312. http://dx.doi.org/10.1007/BF02357859

Karpetschenko GD (1925). On the chromosomes of Phaseolinae. Bull. Appl. Bot. Plant Breed. 14: 143-148.

Kaufmann WK and Paules RS (1996). DNA damage and cell cycle checkpoints. FASEB J. 10: 238-247.

Kops GJ, Weaver BA and Cleveland DW (2005). On the road to cancer: aneuploidy and the mitotic checkpoint. Nat. Rev. Cancer 5: 773-785. http://dx.doi.org/10.1038/nrc1714

Lackey JA (1979). A chromosome atlas of the Phaseoleae (Leguminosae Papilionoideae). Iselya 1: 87-114.

Melo J and Toczyski D (2002). A unified view of the DNA-damage checkpoint. Curr. Opin. Cell Biol. 14: 237-245. http:// dx.doi.org/10.1016/S0955-0674(02)00312-5

Mercado-Ruaro P and Delgado-Salinas A (1998). Karyotypic studies on species of Phaseolus (Fabaceae: Phaseolinae). Am. J. Bot. 85: 1-9. http://dx.doi.org/10.2307/2446547

Mercado-Ruaro P and Delgado-Salinas A (2000). Cytogenetic studies inPhaseolus L. (Fabaceae). Genet. Mol. Biol. 23: 985-987. http://dx.doi.org/10.1590/S1415-47572000000400043

Mercado-Ruaro P and Delgado-Salinas A (2009). Karyotypic analysis in six species of Phaseolus L. (Fabaceae). Caryologia 62: 167-170.

Mok DWSA and Peloquin SJ (1975). The inheritance of three mechanisms of diplandroid (2n pollen) formation in diploid potatoes. Heredity 35: 295-302. http://dx.doi.org/10.1038/hdy.1975.100

Ramalho MAP, Abreu AFB and Santos JB (2005). Genetic progress after four cycles of recurrent selection for yield and grain traits in common bean. Euphytica 144: 23-29. http://dx.doi.org/10.1007/s10681-005-5694-x

Ramanna MS and Jacobsen E (2003). Relevance of sexual polyploidization for crop improvement-A review. Euphytica 133: 3-18. http://dx.doi.org/10.1023/A:1025600824483

Singh SP and Gutierrez JA (1984). Geographical distribution of the $\mathrm{DL}_{1}$ and $\mathrm{DL}_{2}$ genes causing hybrid dwarfism in Phaseolus vulgaris L., their association with seed size, and their significance to breeding. Euphytica 33: 337-345. http://dx.doi.org/10.1007/BF00021130

Singh SP and Urrea CA (1995). Inter and intra racial hybridization and selection for seed yield in early generations of common bean, Phaseolus vulgaris L. Euphytica 81: 131-137. http://dx.doi.org/10.1007/BF00025424

Souza TLPO, Ragagnin VA, Melo CLP, Arruda KMA, et al. (2005). Phenotypic and molecular characterization of cultivar BRSMG Talismã regarding the principal common bean pathogens. Crop Breed. Appl. Biotechnol. 5: 247-252. http:// dx.doi.org/10.12702/1984-7033.v05n02a17

Vieira C, Borém A, Ramalho MAP and Carneiro JES (2005). Melhoramento do feijão. In: Melhoramento de espécies cultivadas (Borém A, eds). UFV, Viçosa, 301-391.

Vilarinho LBO, Vilarinho AA, Moreira MA and Barros EG (2004). Evaluation of the Milionário bean cultivar as bridgecrossing between 'Rudá' and 'Jalo EEP 558'. Crop Breed. Appl. Biotechnol. 4: 241-243.

Wander AE (2014). Socioeconomia. In: Informações técnicas para o cultivo do feijoeiro-comum na Região CentralBrasileira: 2015-2017 (Ramalho MAP, Abreu AFB, Guilherme SR, eds). UFLA, Lavras, 15-35. 